\title{
Skołoszów 16-A Spatial Arrangement of the Eneolithic Settlement of the Funnel Beaker Culture in the Rzeszów Foothills (South-Eastern Poland) in the Light of Previous Excavations and Geophysical Survey
}

\author{
Dariusz Króla ${ }^{a^{*}}$ Jakub Niebieszczański ${ }^{\mathrm{b}}$ \\ anstitute of Archaeology of the Rzeszów University, Moniuszki 10 Street, 35-015 Rzeszów, Poland \\ ${ }^{b}$ Faculty of Archaeology Adam Mickiewicz University in Poznań, Uniwersytetu Poznańskiego 7 Street, 61-614 Poznań, Poland
}

\section{ARTICLE INFO}

\section{Article history:}

Received: $2^{\text {nd }}$ January 2019

Accepted: $25^{\text {th }}$ November 2019

DOI: http://dx.doi.org/ 10.24916/iansa.2019.2.2

Key words:

Eneolithic

Funnel Beaker culture

non-invasive survey

geomagnetic

excavations

spatial arrangement

\begin{abstract}
$A B S T R A C T$
In recent years, numerous sites of the Eneolithic Funnel Beaker culture (FBC) have been identified in the Rzeszów Foothills (south-eastern Poland). Among them, a large settlement in Skołoszów 16 seems to be particularly significant due to its internal characteristics. In order to determine its extent, spatial arrangement and chronology, an interdisciplinary investigation (including excavations and a noninvasive geophysical survey) was carried out in 2017-2018. As a consequence of two seasons of field work campaigns, we have recognized numerous morphologically diverse features (mainly pits) and the settlement (cultural) layer. Excavations documented the intense usage of the settlement's space which encouraged carrying out a geophysical survey over the wider area of the site. The magnetic anomaly distribution reflects many presumable anthropogenic features. Several particular concentrations of features visible on the magnetometry image seem to be related with the FBC, thus delimiting the spatial extent of the site. Based on the geophysical picture, it was possible to estimate that the site measured at least $65 \times 40 \mathrm{~m}$, while the excavations conducted revealed that the settlement was comprised of numerous pits and one settlement layer.
\end{abstract}

\section{Introduction}

In the last decade, much progress has been made in studies on the settlement patterns of the Eneolithic Funnel Beaker culture (hereinafter FBC) in the eastern part of the Rzeszów Foothills in south-eastern Poland. During rescue archaeological investigations preceding the construction of the A4 highway, non-megalithic long barrows (Król et al., 2014) and spatially-diverse stable settlements - previously unknown in this area - were excavated (e.g. Rybicka et al., 2014; 2016; Dębiec et al., 2015; Sznajdrowska, 2016). These results shed new light on FBC settlement patterns in south-eastern Poland ( $c f$. Czopek and Kadrow, 1987; Zych, 2008; Nowak, 2009). They then also became a starting point to initiate detailed micro-regional studies, which led to the identification and/or verification of several dozens of further sites of this cultural phenomenon (e.g. Rogoziński, 2014;

*Corresponding author. E-mail: kroldrk@gmail.com
Rybicka, 2016; Sieradzka and Głowacz, 2017; Król, 2017; 2018). One of the most significant achievements of these investigations was the identification of a new settlement in Skołoszów 16 - one of the largest FBC sites located south of the upper Vistula (cf. Rybicka et al., 2014; Król, 2017; 2018). This settlement was discovered in 2016 during a surface survey mission. The dispersion of sherds within an area of several hectares indicates the possibility of intense habitation in this place by FBC people (Król, 2017; cf. Król, 2018). In order to verify this hypothesis, as well as determine the extent, spatial arrangement and chronology of the settlement, excavation and non-invasive geophysical surveys were carried out. Magnetic prospection had already showed its potential in investigating other Eneolithic sites in the close-by area of Skołoszów 7, where numerous funeral features were revealed (Cwaliński et al., 2018). Therefore, it was decided to use this method to investigate Skołoszów 16, which was comprised of the same geological formation of loess sediments, providing a clear magnetic background. 


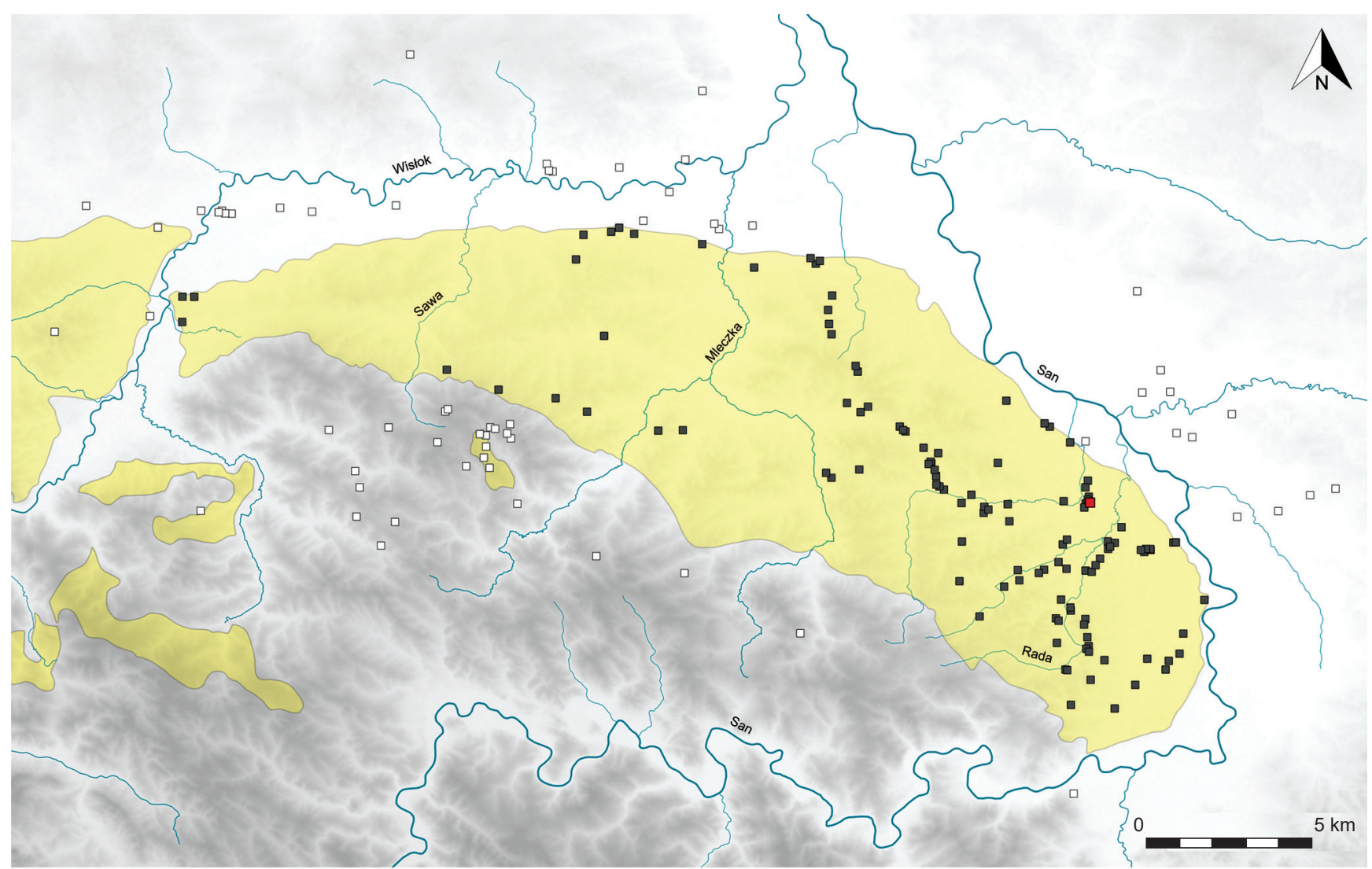

$\mathrm{a} \square \mathrm{b} \square \mathrm{c}$

Figure 1. Distribution of the FBC in the Rzeszów Foothills. a - Skołoszów 16 settlement; b - others sites in the studied area; $\mathrm{c}-$ others sites in the neighbouring areas.

\section{Location of settlement}

The settlement in Skołoszów 16 is located in the northeastern region of the Rzeszów Foothills (Figure 1) on a loess zone in the south-eastern part of the Sandomierz Basin (Kondracki, 1988). It is situated on a slightly flattened small hill, on the right bank of the valley of the Leg Rokietnicki

River, about $380 \mathrm{~m}$ away from its present-day riverbed and

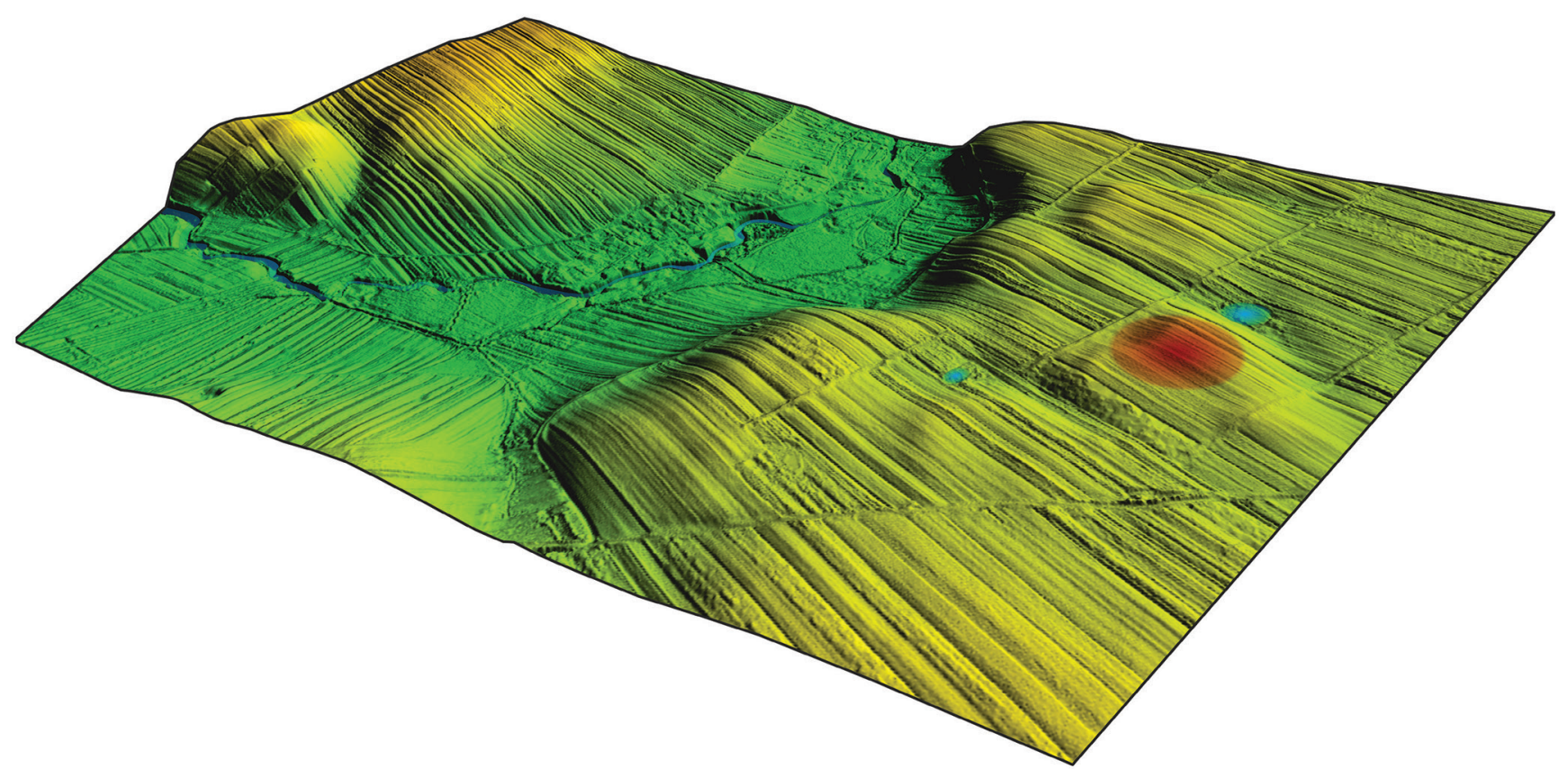

Figure 2. Skołoszów 16, Subcarpathian voivodeship. A 3D model of the settlement location. Red spot - settlement; blue spots - non-outflowing ponds. 
approx. $13 \mathrm{~m}$ above its bottom. In its nearest surroundings, there are also two non-outflowing ponds (Figure 2). This topographic-hydrological configuration of the environment is typical of this part of the Rzeszów Foothills. These conditions favoured the development of the FBC settlement network in south-eastern Poland ( $c f$. Kruk, 1973; 1980; Kruk et al., 1996). Within a radius of $5 \mathrm{~km}$ from the site, up to 30 functionally diverse FBC sites, including one cemetery with two non-megalithic long barrows, have been registered (Król et al., 2014; Król, 2017; 2018, Cwaliński et al., 2018).

\section{Previous excavations}

An archaeological excavation at the new FBC site in Skołoszów 16 was carried out during two fieldwork seasons in 2017 and 2018. The first season aimed to check whether the settlement identified during the surface survey mission could be prospective for excavation and to examine its state of preservation. To this end, preliminary excavations were realized and provided a number of valuable items of information, which are presented below.

As a consequence of the excavation of two small trenches with a total surface of $32 \mathrm{~m}^{2}$, we have recognized 8 diverse features and a settlement layer of $0.4 \mathrm{~m}$ thickness (Figure 3). In the context of these features, as well as the cultural layer we have identified numerous FBC sherd and flint assemblages ( $c f$. Król, 2018). The presence of relatively well-preserved anthropogenic relics and particularly distinct clustered features (Figure 3) has confirmed the scientific importance of this site and justified the second season of the excavation. This excavation carried out in an area of ca. $100 \mathrm{~m}^{2}$ resulted in the identification of another 17 diverse features, especially in the western sector (Figure 3). As in the case of the preliminary excavations in 2017, numerous artefacts relating to FBC were identified. Sherds that imitate

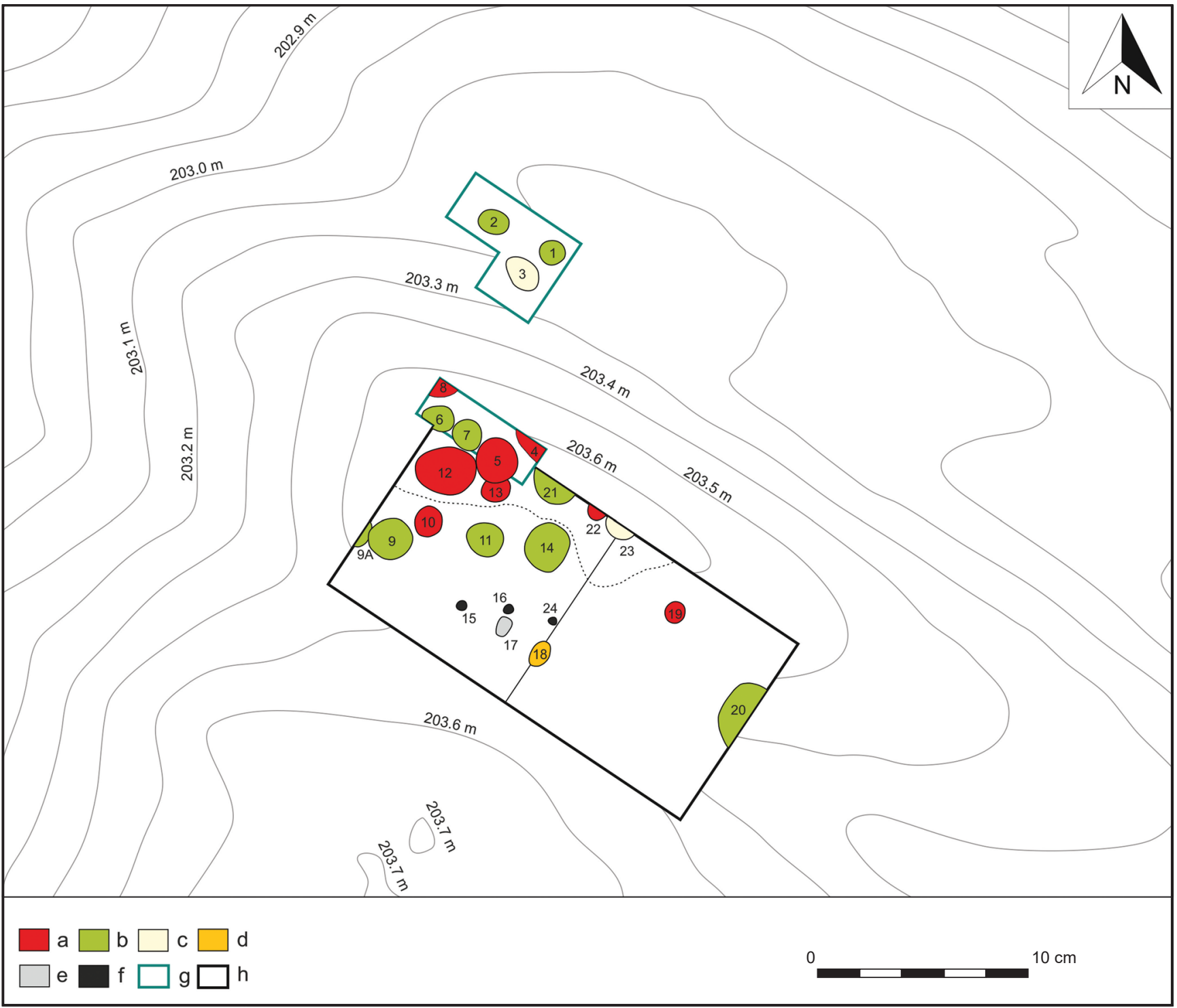

Figure 3. Skołoszów 16, Subcarpathian voivodeship. The distribution of excavated FBC features: $\mathrm{a}$ - trapezoidal pits; $\mathrm{b}-$ tubular pits, $\mathrm{c}-$ rectangular pits, $\mathrm{d}$ - plausible hearth; $\mathrm{e}$ - unknown pits; $\mathrm{f}$ - postholes; $\mathrm{g}$ - area excavated in $2017 ; \mathrm{h}$ - area excavated in 2018. 
Table 1. Skołoszów 16. Basic specification of features.

\begin{tabular}{|c|c|c|c|c|c|}
\hline Feature no. & Feature type & Cross-section & Top size (m) & Depth (m) & Backfill \\
\hline 1 & pit & tubular & $1.22 \times 1.14$ & 0.32 & uniform \\
\hline 2 & pit & tubular & $1.42 \times 1.12$ & 0.30 & uniform \\
\hline 3 & pit & rectangular & $1.88 \times 1.30$ & 0.35 & uniform \\
\hline 4 & pit & trapezoidal & unknown* & 0.42 & uniform \\
\hline 5 & pit & trapezoidal & $2.08 \times 1.05$ & 0.68 & stratified \\
\hline 6 & pit & tubular & $1.47 \times 1.45$ & 0.42 & uniform \\
\hline 7 & pit & tubular & $1.58 \times 1.21$ & 0.40 & uniform \\
\hline 8 & pit & trapezoidal & unknown* & 0.50 & uniform \\
\hline 9 & pit & tubular & $2.06 \times 1.95$ & 0.48 & uniform \\
\hline $9 \mathrm{~A}$ & pit & tubular & unknown* & 0.42 & uniform \\
\hline 10 & pit & trapezoidal & $1.45 \times 1.26$ & 0.41 & uniform \\
\hline 11 & pit & tubular & $1.75 \times 1.59$ & 0.64 & uniform \\
\hline 12 & pit & trapezoidal & $2.87 \times 2.26$ & 0.76 & stratified \\
\hline 13 & pit & trapezoidal & $1.19 \times 1.35$ & 0.35 & uniform \\
\hline 14 & pit & tubular & $2.36 \times 2.07$ & 0.65 & uniform \\
\hline 15 & posthole & irregural & $0.48 \times 0.46$ & 0.25 & uniform \\
\hline 16 & posthole & irregular & $0.46 \times 0.42$ & 0.22 & uniform \\
\hline 17 & unknown & unknown & $0.88 \times 0.64$ & 0.15 & uniform \\
\hline 18 & hearth & basin & $1.20 \times 0.81$ & 0.12 & uniform \\
\hline 19 & pit & trapezoidal & $1.03 \times 0.95$ & 1.05 & stratified \\
\hline 20 & pit & tubular & $3.23 \times ? *$ & 0.75 & stratified \\
\hline 21 & pit & tubular & $2.43 \times ?^{*}$ & 0.72 & uniform \\
\hline 22 & pit & trapezoidal & $0.94 \times ? *$ & 0.80 & stratified \\
\hline 23 & pit & rectangular & $1.52 \times ? *$ & 0.40 & uniform \\
\hline 24 & posthole & irregular & $0.36 \times 0.34$ & 0.12 & uniform \\
\hline
\end{tabular}

* - not fully explored features

the Tripolye culture (hereinafter TC) technology have also been found. These and the typical FBC finds are subject of a separate study.

The excavation revealed a total of 25 morphologically and functionally diverse anthropogenic features, among which the most numerous group might be categorized as storage and/or rubbish pits - features 1-14 and 19-23 (Table 1). In fact, all these pits were conspicuous as being oval in plan and they differed more in size from $0.94 \mathrm{~m}$ to $2.87 \mathrm{~m}$ in diameter (Table 1). More crucial differences were visible in the case of their cross-section and type of backfill. During excavations in Skołoszów 16, we distinguished mainly trapezoidal and tubularshaped pits (Figure 3; Table 1). The first of these were slightly deeper and stratified, while the second had usually a uniform backfill (Table 1). Most of these pits were clustered very densely below the cultural layer and some of them overlapped each other $(e . g$. features $5 \rightarrow 12$ ). However, the deepest and multistratified trapezoidal pit 19 , as well as pit 20 containing peculiar burnt layers, were situated quite independently of this cluster (Figure 3). Another category within the scope of the examined space were the poorly preserved postholes and the one feature which can be carefully interpreted as a hearth located to the south of pits 11 and 14 (Figure 3). Presumably, all these lattermentioned features might be seen as the remains of a dwelling and its interior.

The spatial arrangement of the features recognized seems interesting and may suggest some preferences as to the functioning and development of the settlement. The occurrence of the cluster of trapezoidal and tubular-shaped pits probably do not indicate the short-term inhabitation of this site, and its more complex structure may be confirmed by the intersections of older pits by younger ones (Figure 3 ). These stratigraphic relationships demonstrate that some pits were not contemporaneous. However, it is intractable to determine their detailed temporal relationships due to the mainly unspecific sherds and lack of a large set of AMS radiocarbon dating. Thus far, only two absolute indicators have been obtained from the context of pits 5 (which disturbed the pit 13) and 6 (Figure 4). Both of these dates Poz-100857 4765 \pm 35 and Poz-100856 4680 \pm 35 suggest that the settlement was inhabited within a period of ca. 3650-3350 BC (cf. Król, 2018).

Only a small section of the settlement was examined and it would be difficult to expect much in the way of general 


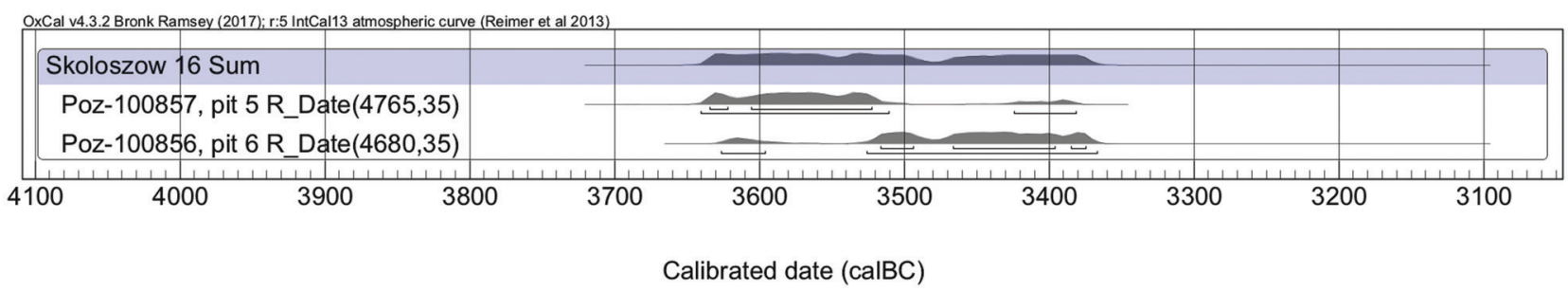

Figure 4. Skołoszów 16, Subcarpathian voivodeship. Radiocarbon dates.

conclusions regarding the spatial arrangement, range and detailed dynamics of its inhabitation based on these limited data. Despite the results of the excavations, it is open to question whether the examined cluster of pits were part of a much larger concentration of features and if there were other clusters within the settlement. This seems justified given the current research experience from the loess area of the eastern part of the Rzeszów Foothills. Such different pit groups have been identified, for instance, in Pawłosiów 52 (Rybicka et al., 2014) and Mirocin 27 (Sznajdrowska, 2016). Undoubtedly, in order to realistically estimate the space of the settlement in Skołoszów 16, large-scale excavations should be carried out. However, preceding these future investigations, we have decided to conduct a geophysical survey in order to locate the most suitable areas for excavations as well as to provide a spatial view of the distribution of archaeological features.

\section{Geophysical survey}

The main aim of the non-invasive research was to investigate the Skołoszów 16 area in order to estimate the potential settlement space of the FBC societies. Due to the indications given by the surface survey conducted in 2016 it was expected to encounter prehistoric remains in the form of pits: this was, moreover, supported by the results of the excavation mission in 2017 and 2018 in the northern part of the site (Król, 2017; 2018). In late 2018, a magnetic prospection was planned for the entire summit and slopes of the small hill (Figure 2), which according to the survey was inhabited by the FBC during Eneolithic times.

The choice of the method was driven by the results that were effectively achieved in the nearby site of Skołoszów 7 in 2016 (Cwaliński et al., 2018). A series of pits, burials, as well as other features, were documented by means of magnetometry thanks to the method-friendly environment, namely the loess coverage of the area. In such good geological circumstances, the archaeological features, which are abundant in the organic material, as well as its differentiated lithological structure, are easily discernible in the geophysical picture (Müller et al., 2017). It was therefore decided to conduct the research based on the same method that was applied in the area of Skołoszów 16 in order to discover the spatial distribution of FBC features, mainly pits, as they were most abundant during the excavations in 2017 and 2018.

\subsection{Methods}

In order to reveal the spatial organization of the FBC settlement, a magnetic method was used. Equipment used during the prospection was the fluxgate magnetometer Bartington Grad601 with one sensor containing two probes located at a distance of a meter from each other. This particular type of magnetometer measures the disturbances in the Earth's magnetic field and provides a measurement of the earth's vertical magnetic gradient. The measured values are expressed in nanoTeslas $(\mathrm{nT} / \mathrm{m})$, while the precision of probing did not exceed $0,1 \mathrm{nT} / \mathrm{m}$.

In the area of Skołoszów 16, a total number of 36 prospection grids were measured, which gave an area of more than 3 ha. Each grid comprised a square of side $30 \mathrm{~m}$ and the measurement transects were separated by a meter interval as the area of prospection was relatively large. Each transect comprised 120 measurements, thus each grid of $30 \times 30 \mathrm{~m}$ consisted of 3600 points with attached $\mathrm{nT} / \mathrm{m}$ values.

It should be mentioned that the field in which the survey was undertaken consisted of a ploughed cultivated surface, which resulted in some disturbances in the magnetic map interpretation (ploughing ridges, etc.). Nevertheless, the homogenous geological subsurface composition, comprised of loess deposits, gave sufficient clearance from any other disturbances, thus allowing a high resolution in the resulting magnetic map.

The magnetic measurements were visualized in GeoPlot and ArcGIS software, using various interpolation models (such as TopoToRaster, Nearest Neighbourhood or Kriging) to obtain the best visual appearance. It was decided to apply the Nearest Neighbourhood method offered by the interpolation toolbox in ArcInfo. The final magnetic view of the site was composed of a raster grid of $0.2 \mathrm{~m}$ resolution and displayed in several $\min / \max$ value ranges in order to aid interpretation of the spatial distribution of magnetic anomalies. It was decided to base the interpretation on the raster values clip from -10 to $10 \mathrm{nT} / \mathrm{m}$, being the one that provided the best quality of discernible anomalies in this particular picture. Further compression of the range of values resulted in representations of the field's ploughing and obstruction in the visibility of archaeological features.

\subsection{Results and discussion}

The area of the Skołoszów site, in terms of magnetic variability, can be described as relatively neutral - as there were no major anomalies which could have obscured the 


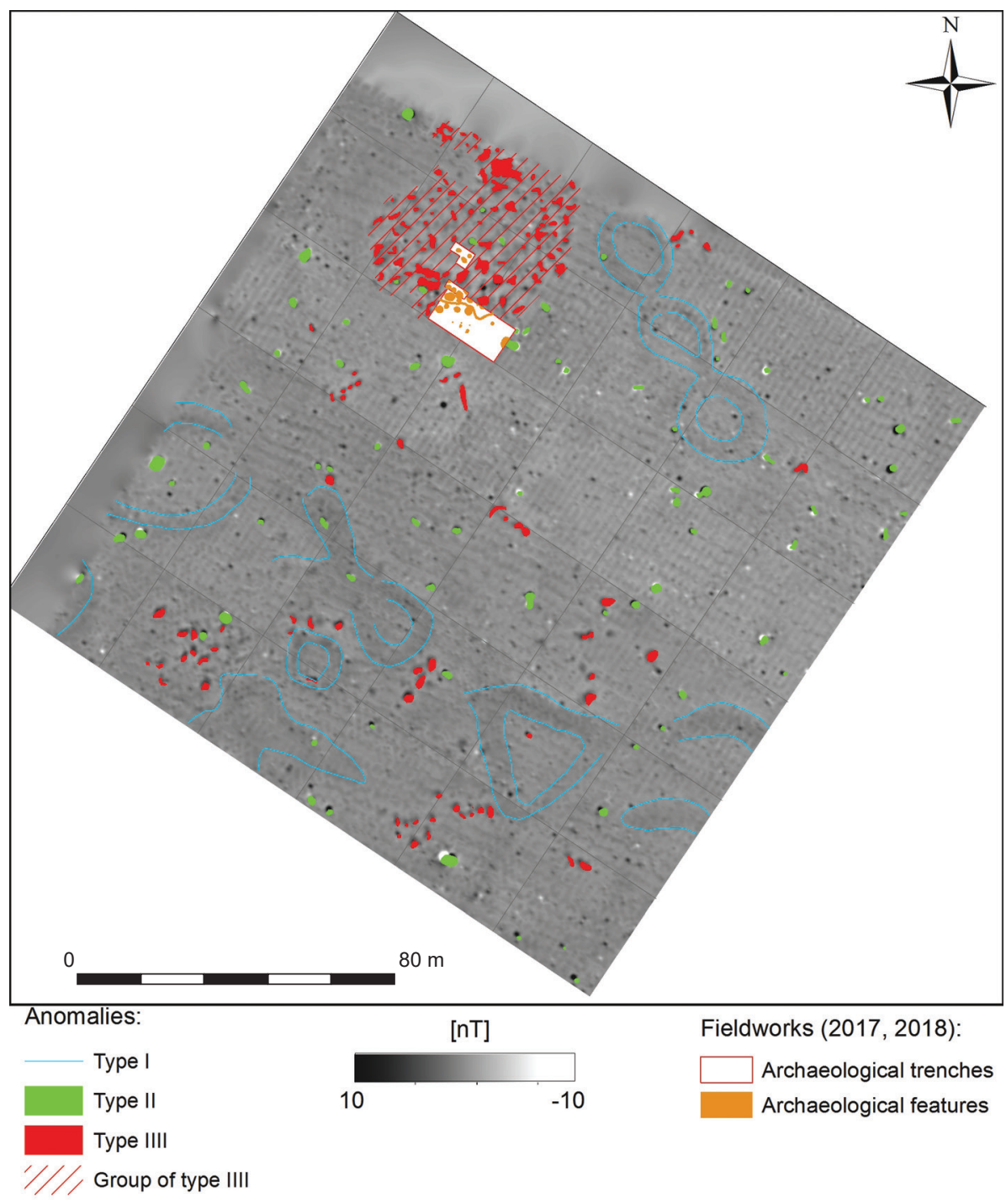

resulting imagery. The maximum registered value reached $70.5 \mathrm{nT} / \mathrm{m}$ and the lowest was $-82 \mathrm{nT} / \mathrm{m}$, while the mean gradient oscillated around $-1.89 \mathrm{nT} / \mathrm{m}$.

The overall analysis of the surveyed area comprised three main anomaly types, distinguished on the basis of their magnetic properties, shapes and spatial distribution. All of them were characterized by their inductive type of magnetism, from which two are believed to be the remnants of prehistoric human activity, while the remaining one is connected with the local geological structures.

The first group of anomalies (type I according to Figure 5) are the elongated or circular passes of insignificantly higher magnetic properties. These structures are located mostly in the south-western and north-eastern parts of the surveyed area. These anomalies seem to draw various spatial arrangements of lines of 1 to $3 \mathrm{~m}$ wide. Regarding their size as well as their regular arrangement, their anthropogenic origin has to be excluded from the interpretation as they supposedly reflect local geological subsurface units (cf. Müller et al., 2017). The genesis of such units could be related to the underground channels of erosive transportation during some earlier stages of landscape development or the
Figure 5. Skołoszów 16, Subcarpathian voivodeship. Interpretation of the magnetic prospection results. The types of anomalies correspond to the typology described in the text. iron-rich infills of depressions. The resulting lithological and geochemical differences can therefore be responsible for their higher magnetic signal.

The second group of features recorded on the resulting picture (type II according to Figures 5 and 6) are anomalies characterized by both single pole signatures and the bipolar orientation of relatively high and low magnetic fields. In total 83 features of this type were recorded within the research area. Their spatial distribution does not show any regular arrangement that would suggest them being indicative of anthropogenic remains. Due to the very high and very low magnetic signals, these features may reflect the position of items of metal waste related to agricultural activity. However, one should be aware that such anomalies can be assigned to metal artefacts from the later stages of prehistory, Medieval or modern times. In fact, they could also be related to military objects remaining from the First World War, as local farmers have reported that even in recent years some shrapnel and artillery shells have been collected by them during agriculture work. Nearby the site of Skołoszów 16, the battle of Radymno took place in 1915 and therefore it should be considered that the discussed anomalies reflect 
Figure 6. Skołoszów 16, Subcarpathian voivodeship. Close-up on the magnetic imagery of the northern accumulation of features of type III with superimposed results of the excavations in 2017 and 2018.

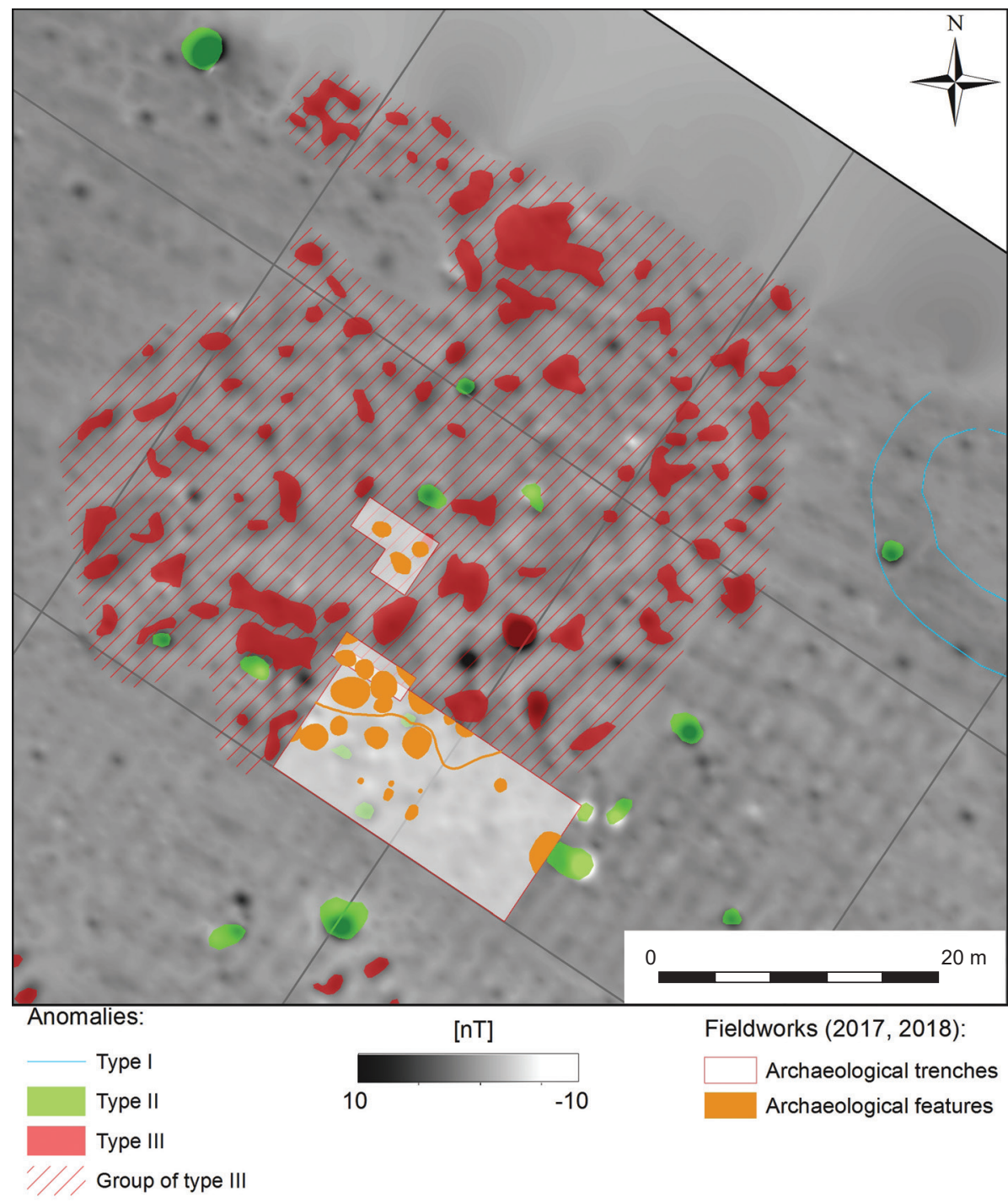

the aforementioned metal elements. Nevertheless, an archaeological explanation can be drawn as well. During the excavations in the northern part of the site, a part of a layer made from burnt daub was encountered in the easternmost part of the trench (Figure 3). Interestingly this feature continues outside the trench on the magnetic map (Figures 5 and 6) as a bipolar anomaly $(+3 /-36 \mathrm{nT} / \mathrm{m})$. It is therefore not excluded that such forms of magnetic features can be interpreted as archaeological features.

The last group (type III according to Figures 5 and 6) consist of single-pole anomalies of relatively small increases in the magnetic gradient (from 2 to $5 \mathrm{nT} / \mathrm{m}$ ). Being the only ones among the above-described features, these should be considered as reflections of archaeological remains such as pits, ditches infilled with different lithological material, or funeral features. Furthermore, the geological background cover of loess seems to support the hypothesis of different sedimentological and geochemical material represented on the magnetometric plan. Identical structures, in terms of shape, have been documented during magnetic prospection in Skołoszów 7 (Cwaliński et al., 2018), which were, moreover, verified during the excavations in 2018 and interpreted as trapezoidal, tubular and rectangular-shaped pits. In Skołoszów 16, a total number of 145 such anomalies have been registered. The highest concentration of such features was observed in the north, while two small separated groups were also encountered in the southern part of the site (Figures 5 and 6).

The first grouping to the north lies in the area which was excavated in 2017 and 2018 and therefore some archaeologically-supported interpretations can be drawn. Within the trenches a series of pits connected to the FBC settlement activity were documented. As is shown by the magnetic imagery, the archaeological trenches were established on the very border of the concentration of pitlike structures. If we were to consider this agglomeration of anomalies as a reflection of a FBC settlement, it would have the dimensions of $65 \mathrm{~m}$ by $40 \mathrm{~m}$ (Figures 5 and 6). However, one should be aware that the northern border of this concentration was not revealed due to the terrain conditions. Therefore, we should expect that this settlement structure continues further to the north. 
The other concentration, relatively smaller than the northern grouping, was recorded in the south, where 12 pit-like anomalies were encountered on the magnetic picture (Figure 5). Their sizes are similar to the ones in the north and therefore they should also be considered as pits of the FBC. There is also another similar small grouping located more to the east, comprising 14 features (Figure 5).

\section{Conclusions}

The results of the interdisciplinary research confirmed the presence of the remains of a large Eneolithic FBC settlement at Skołoszów 16. Its area should be estimated at no less than 3 ha and possibly even more than 4 ha. Most importantly, these studies have highlighted the compelling spatial arrangement of the settlement, in the northern part of which a very extensive cluster of diverse pits was registered (Figures 3, 5 and 6). It appears that only less than 20\% of the features included in it were identified in the excavation missions in 2017-2018. The rest were revealed by noninvasive geophysical prospection in late 2018. The results of the latter studies can be considered to be reliable. For instance, there is a direct correlation of the absence of the archaeological anomalies of type III within the excavation trenches. Therefore, we can observe clear boundaries of the magnetic structures adjacent to the trench borders (Figures 5 and 6). Especially intriguing in this matter is the burnt layer of daub, recorded in pit 20. During the excavations in 2018, it was decided to not expand the trench in order to reveal the spatial boundary of this feature due to the weather conditions. Therefore, on the magnetometric imagery we can observe the continuation of this layer up towards the east (Figures 5 and 6).

Obviously, the picture of the FBC settlement in Skołoszów 16 generated by this interdisciplinary research does not solve all the problems and does not allow us to answer every question fully. This is primarily a static picture of the Eneolithic FBC here, not a dynamic one. In order to make it more dynamic, further research is needed to acquire a statistically-significant pool of indicators of absolute and relative chronology. In the end it has been noteworthy in showing the potential of combining both excavations and magnetic (or non-invasive in general) survey for the investigation of such Eneolithic settlement areas. In the example of Skołoszów 16, it was possible to support the geophysical interpretations with archaeological information, as well as to extrapolate the results of the excavations by the way of magnetic imagery of the site.

\section{References}

CWALIŃSKI, M., NIEBIESZCZAŃSKI, J. and KRÓL, D., 2018. The Middle, Late Neolithic and Early Bronze Age Cemetery in Skołoszów, site 7, Dist. Jarosław, in the Light of the Results of Non-invasive Archaeological Survey in 2016. Acta Archaeologica Ressoviensia, 12, 39-48.
CZOPEK, S. and KADROW, S., 1987. Osada kultury pucharów lejkowatych w Białobrzegach, stan. 5, woj. Rzeszów. Sprawozdania Archeologiczne, 39, 73-88.

DEBIEC, M., DEBBIEC, M. and PELISIAK, A., 2015. Cieszacin Wielki, stan. 41, Pawtosiów, stan. 55, Jankowice, stan. 9. Kompleks osad z epoki neolitu i wczesnej epoki brązu. Rzeszów: Foundation for Archaeological Centre in Rzeszów.

KONDRACKI, J., 1988. Geografia fizyczna Polski. Warszawa: PWN.

KRÓL, D., 2017. Społeczności kultury pucharów lejkowatych na pograniczu Podgórza Rzeszowskiego i Doliny Dolnego Sanu. Studium geograficznoosadnicze. In: M. Rybicka, ed. Wielokulturowe cmentarzysko w Skołoszowie, stan. 7, pow. jarosławski w kontekście osadnictwa z neolitu $i$ wczesnej epoki brązu we wschodniej części Podgórza Rzeszowskiego. Rzeszów: Institute of Archaeology of the Rzeszów University, pp. 5-24.

KRÓL, D., 2018. Studia nad osadnictwem kultury pucharów lejkowatych na lessach Podgórza Rzeszowskiego i Doliny Dolnego Sanu. Materiaty $i$ Sprawozdania Rzeszowskiego Ośrodka Archeologicznego, 39, pp. 39-55.

KRÓL, D., ROGOZIŃSKI, J. and RYBICKA, M., 2014. Cmentarzysko kultury pucharów lejkowatych w Skołoszowie, stan. 7, woj. podkarpackie. In: M. Rybicka, ed. Wschodnie pogranicze grupy poludniowo-wschodniej kultury pucharów lejkowatych. Rzeszów: Institute of Archaeology of the Rzeszów University, pp. 13-37.

KRUK, J., 1973. Studia osadnicze nad neolitem wyżyn lessowych. Wrocław: Ossolineum.

KRUK, J., 1980. Gospodarka w Polsce potudniowo-wschodniej w V-III tysiacleciu p.n.e. Wrocław: Ossolineum.

KRUK, J., MILISAUSKAS, S., ALEKSANDROWICZ, W.S., and ŚNIESZKO, Z., 1996. Osadnictwo $i$ zmiany środowiska naturalnego wyżyn lessowych. Studium archeologiczne $i$ paleogeograficzne nad neolitem $w$ dorzeczu Nidzicy. Kraków: Institute of Archaeology of the Polish Academy of Science.

MÜLLER, J., HOFFMAN, R., KIRLEIS, W., DREIBRODT, S., OHLRAU, R., BRANDTSTÄTTER, L., DAL CORSO, M., OUT, W., RASSMANN, K., BURDO, N. and VIDEIKO, M., 2017. Maidanetske 2013. New excavations at a Trypilia Mega-site. Studien zur Archäologie in Ostmitteleuropa/Studia nad Pradziejami Europy Środkowej, 16, Bonn: Dr. Rudolf Habelt GmbH.

NOWAK, M., 2009. Drugi etap neolityzacji ziem polskich. Kraków: Institute of Archaeology of the Jagiellonian University.

ROGOZIŃSKI, J., 2014. Datowanie bezwzględne osadnictwa neolitycznego ze stanowiska 31 w miejscowości Skołoszów, pow. Jarosław, woj. podkarpackie. In: M. Rybicka, ed. Wschodnie pogranicze 82 grupy poludniowo-wschodniej kultury pucharów lejkowatych. Rzeszów: Institute of Archaeology of the Rzeszów University, pp. 39-54.

RYBICKA, M., 2016. Nowe dane w kwestii datowania kultury pucharów lejkowatych na Podgórzu Rzeszowski. Materiaty $i$ Sprawozdania Rzeszowskiego Ośrodka Archeologicznego, 38, pp. 69-83.

RYBICKA, M., KRÓL, D. and ROGOZIŃSKI, J., 2014., Pawłosiów, stan. 52, woj. podkarpackie. Osada kultury pucharów lejkowatych. In: M. Rybicka, ed. Wschodnie pogranicze grupy poludniowo-wschodniej kultury pucharów lejkowatych. Rzeszów: Institute of Archaeology of the Rzeszów University, pp. 67-256.

SIERADZKA, E. and GŁOWACZ, M., 2017. Materiały kultury pucharów lejkowatych ze stanowiska $31 \mathrm{w}$ Skołoszowie, pow. jarosławski, woj. podkarpackie. In: M. Rybicka, ed. Wielokulturowe cmentarzysko $w$ Skołoszowie, stan. 7, pow. jarosławski w kontekście osadnictwa z neolitu i wczesnej epoki brązu we wschodniej części Podgórza Rzeszowskiego. Rzeszów: Institute of Archaeology of the Rzeszów University, pp. 71-103. SZNAJDROWSKA, A., 2016. Osada kultury pucharów lejkowatych na stanowisku 27 w Mirocinie. In: M. Mazurek and A. Sznajdrowska, eds. Stanowiska 24, 25 i 27 w Mirocinie, gm. Przeworsk. Część 1. Osadnictwo późnopolgarskie i kultury pucharów lejkowatych. Rzeszów: Foundation for Archaeological Centre in Rzeszów, pp. 29-58.

ZYCH, R., 2008. Kultura pucharów lejkowatych w Polsce poludniowo. Rzeszów: Institute of Archaeology of the Rzeszów University. 